УДК 633.330.338.339.1

https://doi.org/10.47533/2020.1606-146X.70

\author{
$A^{*}$ SMAGULOV \\ Al-Farabi KazNU, Almaty, Republic of Kazakhstan \\ e-mail:smagulov35@mail.ru
}

\title{
FOOD SECURITY MANAGEMENT IN AN INNOVATIVE ECONOMY
}

\begin{abstract}
The article deals with the topic of food security and marketing food sovereignty of Republic of Kazakhstan. The authors analyzed the state of food security in the Republic of Kazakhstan on the criteria of physical and economic access, quality and food safety. Measures of supporting the country's food security are proposed.
\end{abstract}

Key words: affordability, accessibility, product quality, energy value.

Kazakhstani legislation defines food security as: "food security, which provides for the state of economic security, including the agro-industrial complex, in which the state is able to ensure physical and economic access to the population of high-quality and safe food products sufficient to meet physiological consumption standards and population growth" $[1,4,10,11,17]$.

The purpose of the study is to consider the current state of food security in the Republic of Kazakhstan and determine the possibilities for solving existing problems.

Materials and research methods

Scientific research was carried out on the basis of agribusiness management sectors using statistical materials (data from the Committee on Statistics of the Ministry of National Economy of the Republic of Kazakhstan), general scientific and specific research methods.

Introduction. In accordance with the rules of monitoring the state of food security, the criteria for ensuring food security are: physical accessibility of food products; affordability of food products; food safety guarantee $[2,19,20]$.

The physical availability of food is largely determined by the development of trade infrastructure. In Kazakhstan, according to the Committee on Statistics of the Ministry of National Economy of the Republic of Kazakhstan [3-21], there are 117034 retail stores selling consumer goods, including trading houses. At the same time, the distribution network in urban areas is being enlarged, supermarkets selling food products are appearing. Commodity supply of rural residents is provided by individual entrepreneurs, and for the main food products (meat, milk, eggs, etc.) is provided through production in personal subsidiary plots. Part of the urban population also provides for the consumption of potatoes, vegetables, berries and fruits through the production of personal plots and summer cottages. To determine physical accessibility, the availability of food products is monitored (a list of 65 items of bakery, cereal, pasta, dairy, fish, meat, food and taste products) in the trading network of cities of the country [3]. Analysis of the results of this monitoring shows a total of $100 \%$ availability of the indicated items of goods for sale. In addition, physical accessibility is also determined by domestic production, the country's comparative advantages in the production of basic food products, and the effectiveness of this production. [8, 9, 12,15].

Research methodology and results. According to the FAO methodology, an important indicator of monitoring food security is an indicator of the level of food deprivation, that is,

*Адрес для переписки. E-mail: smagulov35@mail.ru 
the proportion of the population whose caloric intake is below the minimum acceptable level. A country is considered protected in terms of food security, when the proportion of people suffering from hunger is very low (less than 5 percent). When the level of food deprivation exceeds 35 percent, the problem of combating hunger arises in the country. According to the international classification of the World Food Organization (FAO), nutrition at the level of 2150 calories characterizes the conditions of constant malnutrition. The normal level for a person is 2600 calories.

Data analysis shows that the consumption of all food products, such as meat and meat products, fish and seafood, milk and dairy products, eggs, oils and fats, fruits and vegetables decreases with an increase in the number of household members [6-7].

Households spending more than $70 \%$ on food products account for $3.8 \%$, while households with one child under the age of 18 make up only $2.6 \%$. At the same time, in families with four, five children or more, food expenses increase and their share grows and makes up 7.2 and $12.8 \%$, respectively [5-13].

In many respects, the level of consumption also depends on the price level. As a result of the financial crisis, food prices increased. In 2018, the highest price index (September 2014 to September 2017.) was noted for rice - 120.1; for flour - 113.5; for cheeses - 117.4; sugar - 119.2; for other groups of goods up to $111.0 \%$. A decrease in the price index was noted for such products as cereals - 96.6 and vegetable oil $-95.0 \%$. The affordability of food products depends on real income, price levels, and the distribution of real income. In a country with traditional foundations in demography, targeted social assistance is needed to provide food for large families. An analysis of food security problems shows that the higher the poverty level in a country, the more starving and undernourished the population, which affects the country's gene pool. Rising prices, unemployment leads to the fact that most of the food purchased in bazaars, spontaneous markets, from private owners and does not meet the requirements of quality and safety, storage, transportation of products. The population in search of low prices and natural. She does not think about the safety of products and the quality of nutrition, which affects the level of quality and longevity, the health of the nation. $[14,18,19]$.

Accordingly, the third component of increasing the level of food security of the nation is improving the quality and safety of food products.

In 2018, the Technical Regulation Committee verified 4,584 enterprises. Violations of legal requirements were found in 2726 enterprises, which is about $60 \%$ of the total number of audited. Based on the results of inspections, the sale of more than 16 thousand batches of various products of unsatisfactory quality and lacking certificates of conformity, or correct labeling totaling more than 4 billion tenge was suppressed. For these violations, 2,537 fines were imposed in the amount of more than 160 million tenge [21 - 22].

In order to control the safety of food products, in 2017, during the inspections of trade objects, $713327 \mathrm{~kg}$ of food products were identified and rejected by the sanitaryepidemiological service of the republic [8]. The reasons for the inconsistency of food products are: inconsistency in terms of organoleptic characteristics - $568514 \mathrm{~kg}$, sales of products with an expired shelf life - $100319 \mathrm{~kg}$, lack of documents confirming safety - 33 $817 \mathrm{~kg}$, lack of labeling and production date - $4742 \mathrm{~kg}$, inconsistency in microbiological indicators $-2175 \mathrm{~kg}$, mismatch in the iodine content in salt - $906 \mathrm{~kg}$ (below the norm - 713 
$\mathrm{kg}$, above the norm - $193 \mathrm{~kg}$ ), mismatch to the standards (flour fortification) - $338 \mathrm{~kg}$, violation of the storage conditions of the products - $330 \mathrm{~kg}$, Compliance with sanitary and chemical indicators - $535 \mathrm{~kg}$.

For violations identified by the state sanitary and epidemiological surveillance authorities, administrative measures were taken, fines were imposed for a total of about 11 million tenge [16-21].

Since the beginning of 2019, in order to control the safety of food products, surveillance authorities have removed and destroyed about 100 tons of food products, these are dairy products - 43 tons, drinks - 21 tons, meat products - 14 tons and confectionery products 10 tons. The study covered 200 food markets, 93 large retail outlets, 12 fairs and 89 retail outlets in 30 cities and 139 rural settlements [22].

Today, FAO experts believe that the two main indicators of the state of international food supply are the volume of carry-over grain reserves in the world remaining in storage until the next harvest, as well as the level of grain production per capita.

The threshold value of the first indicator is considered to be a stock equal to 60 days or $17 \%$ of annual world consumption [6]. A reduction in stocks below this level leads to a sharp increase in world grain prices, to destabilize the world grain market, worsen the world market for importing countries and, indirectly, destabilize other food markets. In Kazakhstan, the volume of carry-over grain reserves is set at 90 days, which corresponds to $25 \%$ of the annual consumption.

Conclusions. To solve the problem of low-income citizens, targeted social assistance is needed with a mechanism for identifying and subsidizing this population group. It is necessary to revise the cost of the food basket and the cost of living, to develop a state program of measures for food aid to the population and stimulate demand for domestic food. [12-17].

Given Kazakhstan's accession to the Eurasian Economic Union, the need to ensure the competitiveness of food products in the competition with such leading food market players as Russia and Belarus, Kazakhstan needs to establish a common food safety system, in particular, to establish a system of control over the quality and safety of imported and exported products. [3,6 13,].

To maintain the country's food security, systemic and fundamental measures are needed:

Improving the system for monitoring, forecasting and controlling the state of food markets and food security.

In order to increase the affordability and price competitiveness of domestic food in the domestic and foreign markets, it is necessary: flexible taxation of agricultural producers, the provision of tax and other benefits, increase the investment attractiveness of the agricultural sector; monitoring the implementation of financial recovery measures undertaken as part of the strategic development of the agricultural sector.

\section{REFERENCES}

1 The Law of the Republic of Kazakhstan "On National Security of the Republic of Kazakhstan" with amendments and additions as of November 7,). - Access mode: http://online.zakon.kz. (2014) 
2 Rules for monitoring food security (as amended by 07/29/). - Access mode: http://online. zakon.kz. (2010)

3 Kazakhstan in 2018 / Statistical Yearbook / in Kazakh and Russian / 484 p. / Committee Assessment of food security of the Republic of Kazakhstan based on data from household surveys to assess living standards . - Access mode: http://www.stat.gov.kz (2019)

4 Sayabek Ziadin, Tatyana Sokira, Zhuldyz Dapenova, Askar Smagulov Assesment of the Conribution of Digital Marketing to Tourism Developent34 IBIMA Conference 13-14 November (2019) Madrid Spain.

5 The program for the development of the agro-industrial complex in the Republic of Kazakhstan for 2013 - 2020 “Agribusiness. - Access mode: http://online.zakon.kz (2013)

6 Baubek Konyrov. In 2018, goods worth 4 billion tenge were rejected in Kazakhstan. [Text] / Baubek Konyrov // T engrinews / - 2018. - Access mode: m.tengrinews.kz/.../v2018-godu-v- Eurasian Union of Scientists (ECU) \# VIII, 2014 / Economic Sciences kazahstane-zabrako.(2018)

8 In Kazakhstan, about 100 tons of low-quality products were destroyed. [Text] / / - Access mode: http: // www.nomad.su/?a=7-201306140011.(2013)

9 Tumbay Z. O. A. Boltaeva Modem application of marketing in the telecommunications industry-(2019)

10 Duishenalieva M. U. Accounting-Analytical and Evaluating Procedures for Defining the Economically Feasible Activities of the Oil Processing Enterprises of Kazakhstan (co-author) (2019) Space and culture India

11 Nurseitova.B. energy Efficiency transp.-log.infrastructure.on the example of Kazakhstan (2019)

12 Dzhumambaev S. K., Kunanbayeva D. A. Operational management. Textbook.- Almaty, (2013).

13 In Kazakhstan, about 100 tons of low-quality products were destroyed. [Text] // - Access mode: http: // www.nomad.su/?a=7-201306140011.(2018

14 Ardak TURGINBAYEVA, Gulzhihan SMAGULOVA, Laura ASHIRBEKOVA, Rilla MALIKOVA Topical issues of management in modern education and ways to solve them International Business Information Management Association-(2019)

15 A. N Turginbayeva, a Tarabella, GA Sadykhanova, Yvanassoglo Entrepreneurial university in Kazakhstan social and economic landscape The Journal of Economic Research \& Business Administration 125 (3), 117-127 (2017)

16 Esengalieva R. G. The impact of port transport-logistics infrastructure and lpi for economic growth: on the example of landlocked countries.(2019).

17 Zhatkanbayev E. B. State regulation of the economy of Almaty: Economics, 2013. - 232 p.

18 G. N. Sansyzbaev, S. N. Sansyzbaev, K. O. Shayakhmetova, J. E. Sadykov, M. J. Tursumbaev To the question of the concept of corporate social Topical issues of management in modern education and ways to solve them International Business Information Management Association-(2019)

19 A.N Turginbayeva, A Tarabella, GA Sadykhanova, Y Tanassoglo Entrepreneurial university in Kazakhstani social and economic landscape The Journal of Economic Research \& Business Administration 125 (3), 117-127 (2017)

20 Esengalieva R. G.The impact of port transport-logistics infrastructure and lpi for economic growth: on the example of landlocked countries.(2019).

21 G. N. Sansyzbayeva, S. N. Sansyzbayev, K. O. Shayakhmetova, Zh. sh. Sadykova, M. Zh. Tursumbayeva On the concept of corporate social responsibility of business in Kazakhstan Vestnik MIEP. No. 1 (18). Pp. 47-63 (2015)

22 Kupeshova Saule Tleukhanovna the ROLE of the STATE in the DEVELOPMENT of INNOVATION IN the country Eurasian Union of Scientists (ESU) \# VIII, 2014 | Economic Sciences

23. Utegali Shedenov social and economic security management Almaty (2014) 


\section{А. СМАҒҰЛОВ}

аль-Фараби атындавы Қазақ ұлттық университеті, Қазақстан

\section{ИННОВАЦИЯЛЫК ЭКОНОМИКАДАҒЫ АЗЫК-ТУЛІК КАУІПСІЗДІГІН БАСКАРУ}

Мақ̆алада Қазақ̆стан Республикасының азық-түлік қауіпсіздігі және азық-түлік егемендігінің маркетингі тақырыбы құарастырылады. Авторлар Қазақстан Республикасының азық-түлік қауіпсіздігінің жай-күйін физикалық және экономикалық қолжетімділік, тамақ өнімдерінің сапасы мен қауіпсіздігі өлшемдері бойынша талдады. Елдің азық-түлік құауіпсіздігін ққолдау шаралары ұсынылды.

Түйін сөздер: қ̧ол жетімділік, өнім сапасы, энергетикалық құндылық.

\section{А. СМАГУЛОВ}

Казахский национальный университет имени аль-Фараби, Казахстан

\section{УПРАВЛЕНИЕ ПРОДОВОЛЬСТВЕННОЙ БЕЗОПАСНОСТЬЮ В ИННОВАЦИОННОЙ ЭКОНОМИКЕ}

В статье рассматривается тема продовольственной безопасности и маркетинга продовольственного суверенитета Республики Казахстан. Авторы проанализировали состояние продовольственной безопасности Республики Казахстан по критериям физической и экономической доступности, качества и безопасности пищевых продуктов. Предложены меры поддержки продовольственной безопасности страны.

Ключевые слова: доступность по ицене, качество продукции, энергетическая иеенность. 